\title{
Udder health of cows changing from tie stalls or free stalls with conventional milking to free stalls with either conventional or automatic milking
}

\author{
M. Hovinen, ${ }^{* 1}$ M. D. Rasmussen, $†$ and S. Pyörälä ${ }^{*}$ \\ ${ }^{*}$ Department of Production Animal Medicine, PO Box 57, University of Helsinki, 00014 Helsinki, Finland \\ †Department of Agricultural Engineering, University of Aarhus, Research Centre Foulum, 8830 Tjele, Denmark
}

\begin{abstract}
Udder health and milk production were monitored in cows transferred from tie stalls or loose housing with conventional milking to loose housing with either automatic or conventional milking. Data were collected from 182 Finnish farms from September 1999 to February 2006. Data from the first year before and first year after the changes were compared. A total of 88 herds changed from conventional milking (CM herds) to automatic milking (AM herds), 29 of which were housed in tie stalls and 59 of which were housed in a loose housing barn before the change. Additionally, 94 $\mathrm{CM}$ herds milked in loose housing barns that had been housed in tie stalls before the change were included. Milk record data consisted of annual herd size, parity, breed, calving dates, test day data [date, milk yield, and cow somatic cell count (SCC)] and records for treatments of clinical mastitis. Calculations were made for energy-corrected milk yield and logarithmic SCC ( $\log \mathrm{SCC})$, proportion of cows at risk that experienced an SCC >200,000 cells/mL for the first time (highSCC), and number of treatments of clinical mastitis within a herd. Cows in tie stalls had higher milk yield (28.5 \pm 0.29 vs. $26.5 \pm 0.46 \mathrm{~kg} / \mathrm{d})$ and a lower $\operatorname{logSCC}(4.86 \pm$ 0.01 vs. $4.95 \pm 0.02$ ) than cows in loose housing barns before the change. After the change, CM herds had slightly better udder health than AM herds because the proportion of cows at risk for highSCC was larger in AM herds (3.3 vs. 2.1\%). The change in milking and housing systems caused a decline of $0.8 \pm 0.25 \mathrm{~kg} / \mathrm{d}$ per cow in energy-corrected milk yield, a slight increase in cow $\operatorname{logSCC}$ (from $4.88 \pm 0.01$ to $4.93 \pm 0.01$ ), and an increase of $0.6 \%$ in the proportion of cows having highSCC (from 2.5 to 3.1). The impact was clearer on herds that began automatic milking. Based on the results, the increase in bulk milk SCC of herds milked automatically in Finland was probably due to reduced separation of mastitic milk in AM herds.
\end{abstract}

Received December 10, 2008.

Accepted April 1, 2009.

${ }^{1}$ Corresponding author: mari.hovinen@helsinki.fi
Key words: udder health, automatic milking, conventional milking, housing system

\section{INTRODUCTION}

In the Nordic countries, dairy cows have traditionally been kept in tie-stall barns and herds have been small. Currently, the dairy industry is undergoing structural changes because small farms are no longer profitable. Farms are becoming larger, and because of high labor costs, automation is becoming more common. This has led to rapid and comprehensive changes in farm management. In Finland, warm loose-housing barns have slatted or concrete floors and stalls covered with rubber mats and bedded with wood shavings, peat, sawdust, or different mixtures of these materials (Hakkarainen, 2007). Bedding is similar in tie-stall barns, and feeding in both types of housing is usually silage based, supplemented with concentrates.

Mastitis is the most frequently treated disease of dairy cows (Østerås et al., 2007). Increased concern about udder health arises when housing or milking systems change on a farm. Udder health is affected by factors related to the environment, cow, and milking (Lievaart et al., 2007). Along with physical changes in the barns, changes in management occur; these include staff time spent per cow, detection of illnesses and estrus, cleanliness, level of exercise, feeding regimens, stress level, and infection pressure. As farms grow larger, the throughput of cows at milking increases, which may lead to breeding of cows with higher milk flow and implementing inferior milking routines. These changes can affect udder health, because cows are bred for higher milk yield, which Koivula et al. (2005) associated with increased incidence of mastitis. Changes in the milking system frequently require changes in the settings of the milking equipment, milking frequency, intervals between milking, procedures for and effectiveness of teat cleaning and udder preparation, means of mastitis detection, and teat dipping. Furthermore, automatic milking (AM) is quarter based, which prevents the spread of IMI between teats of the same cow. The spread of IMI between cows is no longer managed by 
milking order, but can be prevented by flushing of the teat cups between cows.

Large field studies examining the effect of changes in housing or milking systems of dairy cows on udder health have been conducted, but the effect of parallel changes between different systems has not been studied. The effects on udder health of a conversion from tie stalls to loose housing barns have produced inconsistent results (Hultgren, 2002; Bielfeldt et al., 2004). Results on the effect of changing from conventional milking (CM) to $\mathrm{AM}$ are more uniform, indicating deteriorating udder health after the introduction of AM (Rasmussen et al., 2001; Kruip et al., 2002; Poelarends et al., 2004). The aim was to study the effect of a change in milking, a change in housing system, or both on udder health and milk production.

\section{MATERIALS AND METHODS}

\section{Farms}

Data were derived from 182 Finnish farms that had changed their housing system, milking system, or both between September 1999 and February 2006. The year before (period 0) and the year after (period 1) the change were compared.

Contacts for AM herds were supplied by Valio Ltd. (Helsinki, Finland) from their client register. The first 2 automatic milking systems (AMS) were installed in 2000 , and at the end of 2005, the number of AM farms in Finland was 159 (E. Manninen, MTT, Vihti, Finland; personal communication). Farmers of 126 herds with AM were asked to participate and 90 responses were received. A total of 88 AM herds were included, 5 of which had both $\mathrm{CM}$ and AM milking available. Twenty-nine herds were housed in tie stalls and 59 were housed in loose housing barns with CM before converting to AM. In tie stalls, cows were milked with pipeline milking machines, and in loose housing, milking was usually in herringbone milking parlors.

Contacts for CM herds originated from the Agricultural Data Processing Centre Ltd. (Vantaa, Finland) cattle database. Conventional milking herds were selected based on the housing system (loose housing), the year the barn was built or renovated (1999 to 2005), and the mean number of cows $(>40)$. Among farmers of 161 herds, 113 agreed to participate, and data from 83 herds were finally included as herds that had changed from tie-stall barns to loose housing systems. Herds were excluded if data were not available for 1 entire year before or after the change. Some of the AM herds had had an earlier change in housing system from tie stalls to loose housing with CM; data for those 11 herds were included in the data twice, first changing from tie stalls to loose housing with CM and then from loose housing with CM to loose housing with AM, with a minimum of $2 \mathrm{yr}$ between changes. A total of 94 herds were included.

\section{Milk Yield and Udder Health Data}

Farmers were asked about the housing system during period 0 , the date of the change, and the number of cows in AM herds regularly milked conventionally. Agricultural Data Processing Centre Ltd. provided milk record data from 1999 to 2006. The database consisted of annual herd size, parity, breed, calving dates, testday data (date, milk yield, and SCC), and records of mastitis treatments.

Test milkings were carried out at approximately 4-wk intervals. Milk yield of a cow was calculated as the sum of all milkings on the test day in CM and before May 1, 2004, in AM. After this date, the average milk yield of AM cows was calculated by recording milk yields at all milkings of a month and dividing the sum by the number of days the cow was milked. Somatic cell count data were collected approximately every other month from 1 milking on the test day. Somatic cell count was analyzed in dairy laboratories by the Fossomatic technique (Foss Electric, Hillerød, Denmark). Farmers of the AM herds were instructed to use only samples from milkings at a milking interval of longer than $6 \mathrm{~h}$ before sampling. Herd size, parity, number of test milkings, and number of SCC samplings are presented in Table 1. The predominant breeds were Finnish Ayrshires (70.5\%) and Holstein-Friesians (28.7\%).

Data on mastitis treatments were extracted from the health records database in which veterinarians and cattle owners recorded mastitis treatments and treatments for other diseases. In total, 2,890 treatments of acute clinical mastitis were recorded by veterinarians and 99 treatments of mastitis during lactation were recorded by the owner, resulting in a total of 2,989 mastitis treatments. Treatments of the same cow within $1 \mathrm{wk}$ were considered a single event. The number of treatments for subclinical and chronic mastitis was too low to be analyzed; more than $50 \%$ of the herds did not have recorded treatments for subclinical mastitis.

\section{Data Analysis}

Milk yield was expressed as ECM. Logarithmic transformation was used to normalize the distribution of SCC $(\log S C C)$. The percentage of cows on a farm that had composite milk SCC $>200,000$ cells $/ \mathrm{mL}$ for the first time within a 2-yr period (highSCC) was used to explore the number of new cases of mastitis. The highSCC was calculated based on the cows at risk. Cow 
Table 1. Herd size, parity, number of test milkings, and number of SCC samplings of cows tested 1 yr before (period 0) and $1 \mathrm{yr}$ after (period 1) the change in the type of housing system, the type of milking system, or both in herds milked automatically (AM) or conventionally (CM) after the change

\begin{tabular}{|c|c|c|c|c|c|}
\hline \multirow[b]{2}{*}{ Item } & \multirow{2}{*}{$\begin{array}{l}\text { Milking } \\
\text { system }\end{array}$} & \multicolumn{2}{|c|}{ Period 0} & \multicolumn{2}{|c|}{ Period 1} \\
\hline & & Mean & Median (range) & Mean & Median (range) \\
\hline \multirow[t]{2}{*}{ Herd size } & $\mathrm{AM}$ & 38 & $36(12-134)$ & 45 & $42(18-130)$ \\
\hline & $\mathrm{CM}$ & 24 & $22(10-105)$ & 34 & $32(10-121)$ \\
\hline \multirow[t]{3}{*}{ Parity } & $\mathrm{AM}$ & 2.05 & $2(1-11)$ & 2.04 & $2(1-12)$ \\
\hline & $\mathrm{CM}$ & 2.29 & $2(1-11)$ & 2.22 & $2(1-11)$ \\
\hline & & Total count & & Total count & \\
\hline \multirow[t]{2}{*}{ Test milkings } & $\mathrm{AM}$ & 38,190 & & 41,030 & \\
\hline & $\mathrm{CM}$ & 24,658 & & 36,449 & \\
\hline \multirow[t]{2}{*}{ SCC samples } & $\mathrm{AM}$ & 19,466 & & 21,597 & \\
\hline & $\mathrm{CM}$ & 12,001 & & 17,389 & \\
\hline
\end{tabular}

composite milk SCC of $\leq 200,000$ cells $/ \mathrm{mL}$ was suggested as a threshold value for cows with all quarters free of subclinical mastitis (Smith, 1997).

ECM $(\mathrm{kg} / \mathrm{d}$ per cow $)$ and $\operatorname{logSCC}$ were tested with a mixed model (model [1]):

$$
\begin{aligned}
& \mathrm{Y}=\text { Period }+ \text { Barntype } 0+\text { Barntype } 1+(\text { Barntype } 1 \\
& \times \text { Period })+(\text { Barntype } 1 \times \text { Period } \times \text { Parity }) \\
& \quad+\text { Month }+ \text { Year }+ \text { Parity }+ \text { ExpDIM } \\
& \quad+\text { DIM }+(\text { DIM } \times \text { DIM })+\text { Error } .
\end{aligned}
$$

The variable HerdID (herd identification number) was included as a random effect and other variables were included as fixed effects. Period was a year before and after the change. Barntype0 before the change was either tie-stall or loose housing with CM, and Barntype1 after the change was loose housing with either $\mathrm{CM}$ or AM. Parity was included as first, second, or older. The variables ExpDIM (exponential function of DIM), DIM, and (DIM $\times$ DIM) modeled the lactation curves. Month and Year were calendar months and years. The interaction between Period, Barntype1, and Parity tested the effect of different lactations. Model [1] include BovineID (bovine identification number) as a repeated variable having test date as the subject and using the autoregressive structure $[\mathrm{AR}(1)]$. Data were unbalanced regarding breed and breed was left unaccounted for. Herd size was left unaccounted for because it was covered by the fixed effect of Parity and the random HerdID effect.

To test the dichotomous outcome that a cow was associated with highSCC for the first time, a categorical procedure GENMOD was used (model [2]):

$$
\begin{gathered}
\text { highSCC }=\text { Period }+ \text { Barntype } 0+\text { Barntype } 1 \\
+(\text { Barntype } 1 \times \text { Period })+\text { Month }+ \text { Year }+ \text { Parity } \\
+ \text { ExpDIM }+ \text { DIM }+(\text { DIM } \times \text { DIM })+\text { Error. }[2]
\end{gathered}
$$

The variable BovineID within herd was included as a repeated subject. The outcome was a logit value for the probability of having highSCC. Transformation of the logit values gave the proportion of cows with highSCC.

In addition, least squares mean values for milk yield, $\operatorname{logSCC}$, and the proportion of highSCC cows were counted over the months before and after the change to study the temporal effect of the change by substituting Period with Month relative to the change in models [1] and [2], yielding models [1a] and [2a]. The models did not converge for repeated measures of ECM and highSCC, but still produced correct least squares mean values without the repeated statement. These values were used to show the development of ECM and highSCC after the change in housing, in milking system, or both.

Treatments for clinical mastitis as cases per 10,000 cow days within a herd and period were tested with a mixed model (model [3]). Treatments were log-transformed before analysis to normalize the distribution:

$$
\begin{gathered}
\text { Treatments }=\text { Period }+ \text { Parity }+ \text { Barntype } 0 \\
+ \text { Barntype } 1+(\text { Barntype } 1 \times \text { Period }) \\
+(\text { Barntype } 1 \times \text { Period } \times \text { Parity })+\text { Error }
\end{gathered}
$$

Parity was included as first and older. All statistical analyses were done with the SAS statistical program (SAS Institute, 2002).

\section{RESULTS AND DISCUSSION}

\section{Milk Yield}

Overall, ECM decreased by approximately $0.8 \mathrm{~kg} / \mathrm{d}$ per cow from period $0(27.9 \pm 0.25 \mathrm{~kg})$ to period $1(27.1$ $\pm 0.25 \mathrm{~kg} ; P<0.001)$. Cows in tie stalls $(28.5 \pm 0.29$ $\mathrm{kg}$ ) had approximately $2.0 \mathrm{~kg}$ higher ECM than cows in 


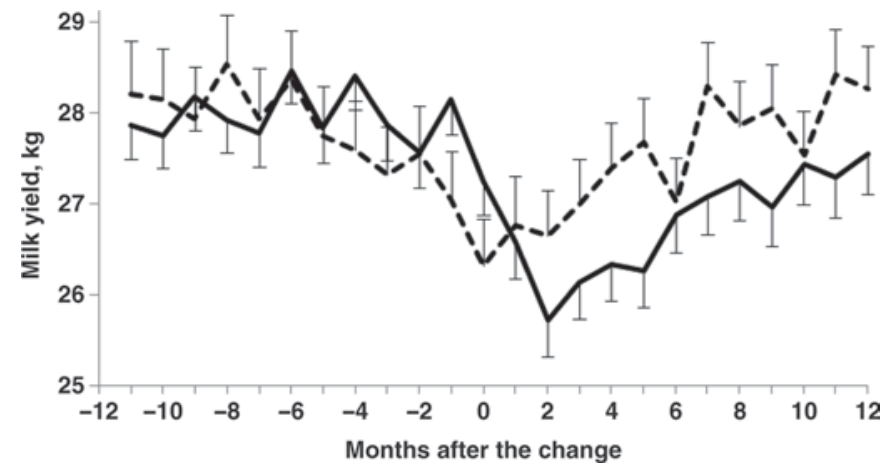

Figure 1. Least squares means $( \pm \mathrm{SE}$ ) of ECM yield (model [1a]) relative to the change from tie stalls or loose housing systems with conventional milking to a) loose housing with conventional milking (94 farms; broken line) or to b) loose housing with automatic milking (88 farms; solid line).

loose housing systems during period $0(26.5 \pm 0.46 \mathrm{~kg}$; $P<0.001)$. Automatic machine-milked cows yielded $27.1 \pm 0.32 \mathrm{~kg}$, whereas CM cows had $28.0 \pm 0.46 \mathrm{~kg}$ in period $1(P=0.17)$. An interaction between period and Barntype1 was seen; from period 0 to period 1, ECM of cows decreased from 27.8 to $26.4 \mathrm{~kg}$ in the AM group, compared with 28.1 to $27.9 \mathrm{~kg}$ in the $\mathrm{CM}$ group $(P<$ 0.001). The ECM of younger AM cows (parities 1 and 2) decreased by approximately $1.1 \pm 0.11 \mathrm{~kg}$, but there was no change for younger CM cows, whereas the ECM of older cows decreased by 2.0 and $1.0 \pm 0.12 \mathrm{~kg}$ in the $\mathrm{AM}$ and CM group, respectively $(P<0.001)$.

A decrease in milk production accompanied the change in housing, in milking system, or both. Figure 1 implies that ECM decreased over a few months before the change and that there was a longer period of depression in ECM during period 1 in AM herds. Effects were more pronounced in the AM group, as indicated by a larger decrease of ECM in the AM group $(1.4 \pm 0.08 \mathrm{~kg}$ vs. $0.2 \pm 0.09 \mathrm{~kg}$ ) and the conceivably longer adaptation period for the change in the system implied by Figure 1. Energy-corrected milk would probably eventually reach the original level in both groups because there was a slightly increasing trend in ECM toward the end of the study period. This finding supports the results of Norell and Appleman (1981), which showed that cows changing from tie stalls to loose housing produced less milk but recovered from the change after 1 full year.

Weiss et al. (2004) found a 15\% decrease in milk yield for the first 20 milkings after changing from CM to $\mathrm{AM}$, even though the milking frequency was increased. They speculated that the decrease could have been due to inhibition of milk ejection, which resulted in incomplete emptying of the udder and reduced milk production caused by enhanced apoptosis of the milk secretory cells. They concluded that cows with a low adaptive capacity would need intensified training after the changeover.

Before the change, cows in tie stalls produced more milk than cows in loose housing barns. Several reasons could explain this finding, including more successful individual feeding of the cows in the tie-stall barns. Mark and Lassen (2007), in a large-scale study in Denmark, found no difference in milk yield between cows in tie stalls and those in loose housing. In studies comparing AM and CM cows in the same barn, Wirtz et al. (2004) reported no difference in milk yield between the groups, even though the mean milking frequency was 2.0 vs. 3.0 times a day in CM and AM. Milk yield was higher for AM cows compared with CM cows (Speroni et al., 2006), but no difference was recorded between primiparous cows. Poelarends et al. (2004) reported a decrease in milk yield on 15 farms that changed from CM to AM for multiparous cows that were $<60$ or $>300$ DIM. Also in our study, the milk production of the older cows decreased more.

Contrary to our findings, Rasmussen et al. (2001) reported an increase in milk yield of approximately 0.5 $\mathrm{kg}$ after a slight decrease over a few months, and Wade et al. (2004) reported an increase of $2 \%$ in milk yield after the introduction of AM, when an increase in milk production over the years was taken into account. In a study by Kruip et al. (2002) on 81 farms converting from twice-daily CM to AM, a parallel increase in daily milk yield of $2.2 \mathrm{~kg}$ was reported. Conventionally milked cows changing from 2 to 3 milkings daily increased their milk production by $5.3 \mathrm{~kg}$. An increase in milk yield was expected with increasing milking frequency, and the unexpectedly small increase in AM was possibly due to irregular milking intervals and fewer visits to the robot on some farms.

The Finnish farms were fairly small before the change, and one-third of them were tie-stall barns before the introduction of AM. Comprehensive changes in farm management, especially for AM herds, probably resulted in a longer time necessary for cows adapting to the system.

Irregular milking intervals in AM may result in lower yields than regular intervals. Hogeveen et al. (2001) showed that although the average milking interval was $9.2 \mathrm{~h}$ on an experimental farm with AM, $27.3 \%$ of the milking intervals were shorter than $6 \mathrm{~h}$ or longer than $12 \mathrm{~h}$. This had a considerable effect on milk production, especially for the high-producing cows. In AM, good management practice includes ensuring an adequate milking frequency of all cows instead of looking at the average milking frequency of the herd. 


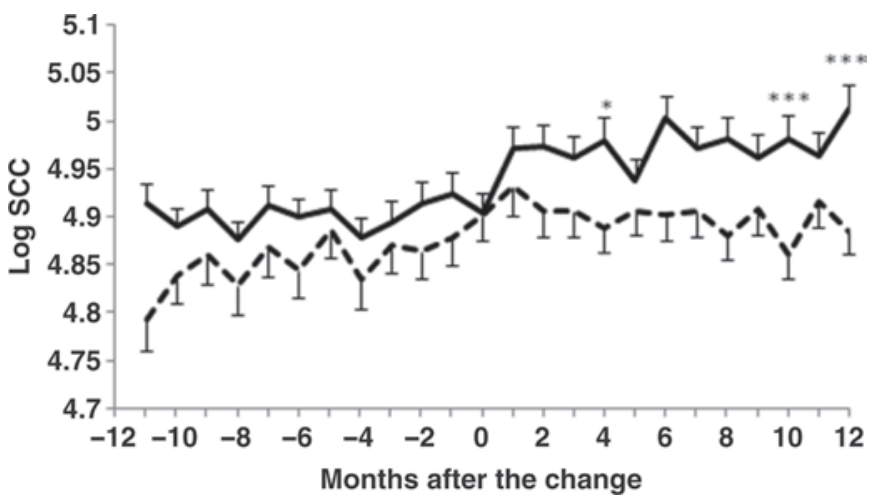

Figure 2. Least squares means $( \pm \mathrm{SE})$ of logarithmic SCC $(\operatorname{logSCC}$; model [1a]) relative to the change from tie stalls or loose housing system with conventional milking to a) loose housing with conventional milking (94 farms; broken line) or to b) loose housing with automatic milking (88 farms; solid line). ${ }^{*} P<0.05$ compared between groups; $* * * P<0.001$

\section{Average LogSCC and Proportion of HighSCC Cows}

The $\log \mathrm{SCC}$ increased from period $0(4.88 \pm 0.01)$ to period $1(4.93 \pm 0.01 ; P<0.001)$. Cows in the tie stalls had lower $\operatorname{logSCC}(4.86 \pm 0.01)$ than cows in loose housing barns during period $0(4.95 \pm 0.02 ; P<0.001)$. No difference in $\operatorname{logSCC}$ between $\mathrm{AM}(4.93 \pm 0.02)$ and $\mathrm{CM}(4.89 \pm 0.02)$ cows in period 1 was recorded. An interaction was found between periods in AM and $\mathrm{CM}$ herds; $\log \mathrm{SCC}$ of AM cows increased from $4.89 \pm$ 0.01 to $4.96 \pm 0.02$ compared with an increase from $4.87 \pm 0.02$ to $4.90 \pm 0.02$ for $\mathrm{CM}$ cows $(P<0.001)$. Older cows showed a greater increase in logSCC than younger cows and increased from $5.00 \pm 0.01$ to 5.09 \pm 0.02 compared with an increase from $4.97 \pm 0.02$ to $5.02 \pm 0.02$ for younger cows $(P=0.018)$. Both the AM and $\mathrm{CM}$ groups had an increase in $\operatorname{logSCC}$ before the change in housing and milking systems (Figure 2), but AM herds continued to a higher level after the change; the difference between groups became significant at mo $4(P=0.015)$ and became highly significant at mo 10 and 12 after the change $(P<0.001)$.

A general increase of $0.5 \%$ was noted in the proportion of new highSCC cows from period 0 to period 1 (2.4 vs. $2.9 ; P=0.001)$. There were no difference in the proportion of highSCC cows between tie-stall barns $(1.8 \%)$ and loose housing $(2.7 \%)$ systems. The proportion of highSCC cows in the AM group reached $3.3 \%$ compared with $2.1 \%$ in $\mathrm{CM}$ cows $(P=0.011)$ in period 1. An interaction existed between periods in the $\mathrm{AM}$ and CM groups; in AM cows, the proportion of highSCC cows increased from 2.8 to $3.8 \%$, whereas in the $\mathrm{CM}$ herds the increase was from 2.0 to $2.2 \%(P=$ 0.006). Increasing age of the cows was associated with a lower proportion of highSCC cows between parities (parities 1,2 and $\geq 3 ; 3.6,2.8$ and 1.8 , respectively; $P$ $<0.001)$.

In our study, cows in tie stalls had milk SCC approximately 17,000 cells $/ \mathrm{mL}$ lower than those in loose housing barns, but the proportion of cows having new highSCC for the first time did not differ. The prevalence of clinical mastitis (Bakken, 1981; Valde et al., 1997), highSCC cows, and subclinical mastitis (Bakken, 1981) was higher in herds housed in tie stalls than in those housed in loose housing. The results of Bakken (1981) were explained by failures in air conditioning, stall dimensions, bedding, and settings of the milking system. In our study, the management of cows in tie stalls appeared adequate.

Milk SCC increased from period 0 to period 1, with approximately 10,000 cells/mL of milk per cow, with a $0.5 \%$ increase in the proportion of highSCC cows. The effect was more substantial in the AM herds. An apparent adaptation period of 2 to 3 mo seemed to occur after the change in milking systems in the AM group (Figure 3). The difference in the proportion of highSCC cows between the 2 groups after the change was significant, although the statistical model could not indicate which months differed. The proportion of highSCC cows appeared to stabilize close to the original values toward the end of the study. Our results support Bielfeldt et al. (2004), who showed an increase in milk SCS of cows changed from tie stalls to loose housing. Hultgren (2002), on the other hand, recorded no changes in the herd prevalence of highSCC cows after changing from tie stalls to free-stall or straw yard systems. Poelarends et al. (2004) showed that the proportion of highSCC cows increased after the introduction of AM for second- and third-parity cows during early lactation. In our study, although the logSCC was higher in the older cows in general, the proportion of cows with highSCC decreased with increasing parity when calculated as percentage of cows at risk. This could be a concern because mastitis at a young age would reduce the cow survival. Poelarends et al. (2004) reported a deterioration of udder health already before the change in milking system, which we support (Figure 2).

Our average cow composite SCC per herd, when changed from CM to AM, was higher after the change, supporting the report of Kruip et al. (2002). This probably occurred because of the irregularity of milking. Short intervals leave less time for teats to recover from milking, which could affect teat condition, and long intervals provide bacteria time to colonize the teat. According to Danish data on 69 farms, logSCC and the proportion of new highSCC cows increased after the introduction of AM (Rasmussen et al., 2001) but decreased after an adaptation period of a few months. In that study, the increase in the proportion of new 


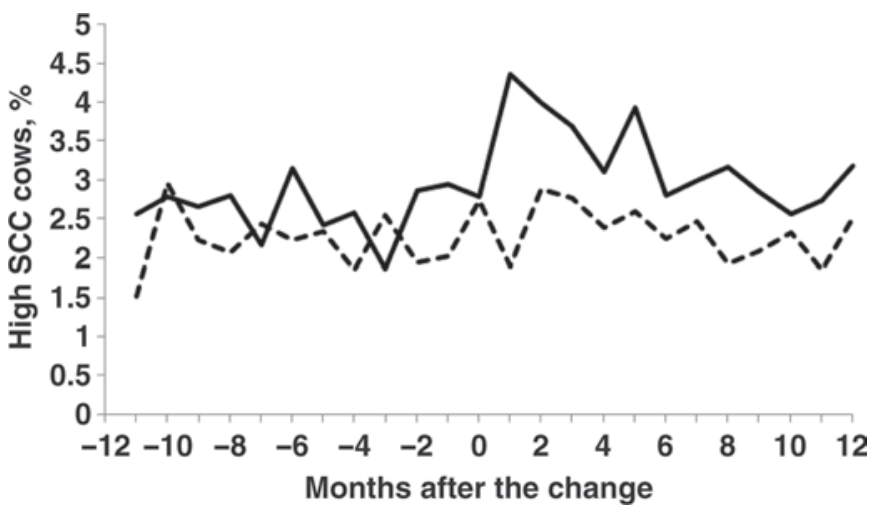

Figure 3. Least squares means of proportion of new highSCC cows $(>200,000$ cells $/ \mathrm{mL}$; model $[2 \mathrm{a}])$ relative to the change from tie stalls or loose housing systems with conventional milking to a) loose housing with conventional milking (94 farms; broken line) or to b) loose housing with automatic milking (88 farms; solid line).

highSCC cows over the first year after the introduction was $1.8 \%$, which is supported by our result of $1.0 \%$ in the AM herds. Greater fluctuations of low and high SCC levels among cows were also recorded, indicating more new infections. A recent experiment by Rasmussen (2006) with 478 AMS farms supported the earlier results; the increase in new highSCC of cows at risk was still present after $4 \mathrm{yr}$ of AM. The increase did not depend on the year of introduction or on the AMS brand. The authors speculated that part of the problem was related to problems in mastitis detection in AM (Rasmussen et al., 2001). Studies comparing AM and CM cows kept in the same barn with differences only in the milking system indicated better udder health in $\mathrm{AM}$ or no differences in udder health (Berglund et al. 2002; Wirtz et al., 2004).

Automatic milking includes some improvements compared with CM. Milking frequency increased in AM, at least for most of the cows (Hogeveen et al., 2001). Increased milking frequency flushes bacteria from the udder more frequently. Quarter-based milking in AM limits the risk for interquarter contamination with mastitis-causing bacteria within a cow and reduces overmilking. Despite these advantages compared with CM, udder health has not been better with AM.

Udder health of individual cows can be monitored regularly by the herd staff in CM. Foremilk is visually inspected, and the udder is inspected twice a day. In AM, automated methods for SCC counting had not yet been developed during this research. Methods for detecting clinical and subclinical mastitis (i.e., electronic conductivity), at least in the previous versions of AM, were not reliable enough for independent separation of milk (Rasmussen, 2004; Hovinen et al., 2006). In AM, milk is not separated from the mastitic quarter only, but all milk of the cow is separated. This, along with the reduced possibility for detecting highSCC cows, may lead to diminished separation of milk with highSCC and an increase in the bulk tank SCC (BMSCC). If detection of mastitis is late, the proportion of new highSCC cows may increase. Cows with undetected mastitis represent an infection risk for other cows. Zecconi et al. (2004) reported from 1 herd with Staphylococcus aureus infections (3.4\% of the cows at the beginning of lactation) that at the end of the study, the infection had spread to $66.7 \%$ of the cows.

The results of our study can be compared with the national data on BMSCC for all Finnish dairy farms, large farms, and AM farms (http://www.maitohygienialiitto.fi/maidon_laatu_autom_03.html). The BMSCC of the AM herds was approximately 25,000 cells $/ \mathrm{mL}$ higher than for the respective conventional large farms (>45 cows) and was 50,000 cells $/ \mathrm{mL}$ higher than on all farms, where BMSCC was approximately 125,000 cells/ $\mathrm{mL}$. A difference between $\operatorname{logSCC}$ in $\mathrm{CM}$ and AM herds was found only in mo 4, 10, and 12 after the change, suggesting that the difference in BMSCC resulted mostly from the decreased separation of highSCC milk in AM. The difference in BMSCC among all Finnish farms (mainly tie-stall barns) and large farms (mainly loose housing) is supported by our results.

\section{Mastitis Treatments}

The number of recorded treatments of clinical mastitis was 4.8/10,000 cows days in period 1 , compared with $4.0 / 10,000$ cow days in period $0(P=0.077)$. No difference in the frequency of recorded treatments for clinical mastitis between barn types was noted during the experimental periods (5.0 for tie stalls vs. 3.9 for loose housing, and 3.7 for CM vs. 5.2 for AM). The interaction between period and Barntype1 was significant $(P=0.050)$; in AM herds, the number of recorded treatments decreased from period 0 to period 1 , from 5.3 to 5.1 treatments per 10,000 cow days, whereas in CM herds, treatments increased from 3.0 to 4.6 treatments per 10,000 cow days. First-lactation cows had fewer treatments than older cows (1.0 vs. 18.9 treatments per 10,000 cow days; $P<0.001)$. For CM herds, first-lactation cows and older cows were treated more often, but in AM herds, first-lactation cows had fewer and older cows had more recorded treatments from period 0 to period 1 (parity 1: CM from 1.1 to 1.5 and AM from 0.8 to 0.6 treatments per 10,000 cow days; older cows: CM from 7.9 to 13.2 and AM from 30.5 to 39.7 treatments per 10,000 cow days; $P<0.001$ ).

When considering that the herds consisted of younger animals after the change, the number of treatments tended to increase from period 0 to period 1 by ap- 
proximately 1.5 treatments in 1 yr per 60 -cow herd. When parity of cows was not taken into account (data not shown), the number of treatments decreased along with the change. The overall effect for AM herds was approximately 0.2 treatments less per year and in CM herds was 3 treatments more from period 0 to period 1 per 60-cow herd. In the study of Hultgren (2002), the proportion of highSCC cows within a herd was not affected, but the frequency of veterinary-treated clinical mastitis and teat injuries was lower after a change from tie stalls to loose housing systems with CM, taking parity into account. The effect lasted for longer than 18 mo. When cows in 533 free-stall barns and 59 tie-stall barns were compared in a Norwegian study, the number of veterinary treatments of clinical mastitis was higher in tie-stall barns than in free-stall barns (Valde et al., 1997). In contrast, in our study the number of treatments of clinical mastitis increased after the change in $\mathrm{CM}$ and for older cows in AM herds, probably because of the impaired udder health of these cows.

This raises the question of why the number of treatments of young cows decreased in AM herds and not in CM herds. Udder health may, for some reason, have been more impaired by the change in CM herds than in AM herds, but this was not supported by the results. The frequency of recorded treatments for clinical mastitis did not necessarily reflect the true incidence of clinical mastitis, but did reflect the mastitis treatment strategies on the farm. The number of cows was higher in AM herds than in CM herds after the conversion. Along with the change toward more intensive farming with increasing herd size, the time spent per cow decreased, which left less time for individual cows. Consequently, farmers may have been focused on treatments at drying off. According to Pedersen and Bennedsgaard (2006), the proportion of cows with a blind quarter (i.e., a quarter that is not milked) increased from 7 to $12.5 \%$ during the first 6 mo after changing to AM. Moreover, mild cases of mastitis may have remained undetected in AM. Bennedsgaard et al. (2004) reported an increase in antibiotic treatments for mastitis on 20 farms after the introduction of AM (0.4 vs. 0.6 treatments/cow year). Some of the farmers increased their treatment frequency because they trusted the alarms created by the automatic mastitis detection system of AMS. This could raise a concern regarding problems with falsepositive alarms in AM (Hovinen et al., 2006).

\section{Sources of Error}

In Finland, SCC was measured independently of the milking interval in the AM herds. This could have affected the SCC results in our study. According to
Olde Riekerink et al. (2007), if the time since the last milking is less than $3 \mathrm{~h}$, even healthy quarters could have an SCC close to 200,000 cells/mL. They found that the geometric mean SCC increased until $7 \mathrm{~h}$ after milking. Their explanation relied on the hypothesis of a high influx of cells shortly after milking, followed by dilution with a large milk volume hours later. They established a diurnal variation in SCC and considered that these effects should be accounted for when interpreting the results of test milkings. Information on milking frequency was not available in our study, but farmers were instructed to sample only if the time since the last milking was $>6 \mathrm{~h}$, which makes the results comparatively reliable.

After 2004, milk yield was measured as a monthly mean in AM cows. This change did not affect the standard deviation of ECM of cows milked with AM, nor did it result in differences between the different types of barns before or after this date (data not shown). There was no statistical reason for not treating these groups equally. A total of 29 farms began before the change in the sampling system. The sample of herds was considered representative of the complete group of $\mathrm{AM}$ and $\mathrm{CM}$ herds because fewer than $30 \%$ declined to participate. The proportion was the same for both groups; therefore, the results are comparable.

\section{CONCLUSIONS}

Udder health deteriorated and milk yield decreased after a change from tie-stall or loose housing barns with $\mathrm{CM}$ to loose housing with either CM or AM. Effects were more substantial for cows in the AM herds. The proportion of new highSCC cows was most pronounced during the adaptation period of 2 to 3 mo after the change in AM herds. The increase in logSCC was small but constant. Udder health was slightly better in CM cows after the change. Based on this study, the increased BMSCC of herds milked automatically in Finland may result mostly from diminished separation of mastitic milk in AM herds.

\section{ACKNOWLEDGMENTS}

The authors thank Valio Ltd. (Helsinki, Finland), and especially Ari Mäkelä, for using their client register and for gathering permissions from the AM farms, and Agricultural Data Processing Centre Ltd. (Vantaa, Finland), and especially Sinikka Tommila, for providing the data. This study was funded by the Walter Ehrström Foundation (Helsinki, Finland) and the Mercedes Zachariassen Foundation (Helsinki, Finland). 


\section{REFERENCES}

Bakken, G. 1981. Environment and bovine udder diseases in the loose housing system for dairy cows with reference to relevant data from the cowhouse system. Acta Agric. Scand. 31:445-451.

Bennedsgaard, T. W., S. Elvstrøm, and M. D. Rasmussen. 2004. Selection of cows for treatment of udder infections in AMS herds. Pages 209-214 in Automatic Milking-A Better Understanding. A. Meijering, H. Hogeveen and C. J. A. M. de Koning, ed. Wageningen Academic Publishers, Wageningen, the Netherlands.

Berglund, I., G. Pettersson, and K. Svennersten-Sjaunja. 2002. Automatic milking: Effects on somatic cell count and teat-end quality. Livest. Prod. Sci. 78:115-124.

Bielfeldt, J. C., R. Badertscher, K. H. Tölle, and J. Krieter. 2004. Factors influencing somatic cell score in Swiss dairy production. Schweiz. Arch. Tierheilkd. 146:555-560.

Hakkarainen, K. 2007. Lehmien hoitokäytännöt, terveys ja hyvinvointi (Management, health and welfare of dairy cows). Pages 5676 in Lypsykarjapihaton toiminnalliset mitoitusvaihtoehdot (Dimensioning options for dairy free stall barns). T. Kivinen, K. O. Kaustell, K. Hakkarainen, V.-M. Tuure, J. Karttunen, and T. Hurme, ed. MTT:n selvityksiä 137. MTT, Vihti, Finland.

Hogeveen, H., W. Ouweltjes, C. J. A. M. de Koning, and K. Stelwagen. 2001. Milking interval, milk production and milk flow-rate in an automatic milking system. Livest. Prod. Sci. 72:157-167.

Hovinen, M., A.-M. Aisla, and S. Pyörälä. 2006. Accuracy and reliability of mastitis detection with electrical conductivity and milk colour measurement in automatic milking. Acta Agric. Scand., Sect A. $56: 121-127$.

Hultgren, J. 2002. Foot/leg and udder health in relation to housing changes in Swedish dairy herds. Prev. Vet. Med. 53:167-189.

Koivula, M., E. A. Mäntysaari, E. Negussie, and T. Serenius. 2005. Genetic and phenotypic relationships among milk yield and somatic cell count before and after clinical mastitis. J. Dairy Sci. 88:827-833.

Kruip, T. A. M., H. Morice, M. Robert, and W. Ouweltjes. 2002. Robotic milking and its effect on fertility and cell counts. J. Dairy Sci. 85:2576-2581.

Lievaart, J. J., H. W. Barkema, W. D. Kremer, J. van den Broek, J. H. Verheijden, and J. A. Heesterbeek. 2007. Effect of herd characteristics, management practices, and season on different categories of the herd somatic cell count. J. Dairy Sci. 90:41374144 .

Mark, T., and J. Lassen. 2007. Genotype by housing interaction in Danish Holsteins. Interbull Bull. 37:26-28.

Norell, R. J., and R. D. Appleman. 1981. Change of milk production with housing system and herd expansion. J. Dairy Sci. 64:17491755 .

Olde Riekerink, R. G. M., H. W. Barkema, W. Veenstra, F. E. Berg, H. Stryhn, and R. N. Zadoks. 2007. Somatic cell count during and between milkings. J. Dairy Sci. 90:3733-3741.

Østerås, O., H. Solbu, A. O. Refsdal, T. Roalkvam, O. Filseth, and A. Minsaas. 2007. Results and evaluation of thirty years of health recordings in the Norwegian dairy cattle population. J. Dairy Sci. 90:4483-4497.
Pedersen, L. H., and T. W. Bennedsgaard. 2006. Udder health in dairy herds converting to automatic milking systems-Bacteriology and cell count pattern. Pages 26-31 in Proc. Cattle Consulting Days 2006. Frederiksberg Bogtrykkeri, Nyborg, Denmark.

Poelarends, J. J., O. C. Sampimon, F. Neijenhuis, J. D. H. M. Miltenburg, J. E. Hillerton, J. Dearing, and C. Fossing. 2004. Cow factors related to the increase of somatic cell count after introduction of automatic milking. Pages 148-154 in Automatic Milking - A Better Understanding. A. Meijering, H. Hogeveen and C. J. A. M. de Koning, ed. Wageningen Academic Publishers, Wageningen, the Netherlands.

Rasmussen, M. D. 2004. Detection and separation of abnormal milk in automatic milking systems. Pages 189-197 in Automatic Milking-A Better Understanding. A. Meijering, H. Hogeveen and C. J. A. M. de Koning, ed. Wageningen Academic Publishers, Wageningen, The Netherlands.

Rasmussen, M. D. 2006. Automatic milking and udder health: An overview. Pages 368-375 in Comp. of 24th World Buiatrics Congr., Nice, France. H. Navetat and F. Schelcher, ed. World Assoc. Buiatrics, Paris, France.

Rasmussen, M. D., J. Y. Blom, L. A. H. Nielsen, and P. Justesen. 2001. Udder health of cows milked automatically. Livest. Prod. Sci. $72: 147-156$.

SAS Institute. 2002. SAS OnlineDoc, Version 9.1. SAS Inst. Inc., Cary, NC.

Smith, I. 1997. Recommendations for presentation of mastitis-related data. Int. Dairy Fed. Bull. 321:6-30.

Speroni, M., G. Pirlo, and S. Lolli. 2006. Effect of automatic milking systems on milk yield in a hot environment. J. Dairy Sci. 89:46874693.

Valde, J. P., D. W. Hird, M. C. Thurmond, and O. Osterås. 1997. Comparison of ketosis, clinical mastitis, somatic cell count, and reproductive performance between free stall and tie stall barns in Norwegian dairy herds with automatic feeding. Acta Vet. Scand. 38:181-192.

Wade, K. M., M. A. P. M. van Asseldonk, P. B. M. Berentsen, W. Ouweltjes, and H. Hogeveen. 2004. Economic efficiency of automatic milking systems with specific emphasis on increases in milk production. Pages 62-67 in Automatic Milking-A Better Understanding. A. Meijering, H. Hogeveen, and C. J. A. M. de Koning, ed. Wageningen Academic Publishers, Wageningen, the Netherlands.

Weiss, D., S. Helmreich, E. Möstl, A. Dzidic, and R. M. Bruckmaier. 2004. Coping capacity of dairy cows during the change from conventional to automatic milking. J. Anim. Sci. 82:563-570.

Wirtz, N., E. Tholen, H. Spiekers, W. Zahres, E. Pfeffer, and W. Trappmann. 2004. Comparison between automatic and conventional milking concerning milk performance and feed amount. Zuchtungskunde 76:321-334.

Zecconi, A., R. Piccinini, G. Casirani, E. Binda, and L. Migliorati. 2004. Introduction of AMS in Italian dairy herds: Effects on teat tissues, intramammary infection risk, and spread of contagious pathogens. Pages 161-167 in Automatic Milking-A Better Understanding. A. Meijering, H. Hogeveen and C. J. A. M. de Koning, ed. Wageningen Academic Publishers, Wageningen, the Netherlands. 